\title{
Potensi Pembangkit listrik Tenaga Mikrohidro (PLTMH) di Kabupaten Pegunungan Arfak
}

\section{The Potential of Microhydro Power Plant (MHP) in the Pegunungan ARfak Regency}

\author{
Antonius D. Palintin ${ }^{1, *}$, Erik A. Patandianan ${ }^{2}$, Elias K. Bawan ${ }^{3}$ \\ 1,3Jurusan Teknik Elektro Universitas Papua \\ ${ }^{2} J u r u s a n$ Teknik Geologi Universitas Papua \\ Jl. Gunung Salju, Amban - Manokwari, Indonesia 98314
}

Dikirim: 10 Januari 2020; Disetujui: 4 Juni 2020; Diterbitkan: 29 Juni 2020

\section{Inti Sari}

Pembangkit Listrik Tenaga Mikrohidro (PLTMH) merupakan pembangkit yang berkelanjutan dan ramah lingkungan. Penelitian ini mengkaji tentang potensi PLTMH dengan menentukan debit andalan dan beda tinggi dari beberapa sungai di tiga distrik: Minyambouw, Hingk dan Sururey, Kabupaten Pegunungan Arfak. Hasilnya adalah, potensi daya terbesar di sungai Inggemou Distrik Minyambouw sebesar 32,1 kW dengan net head 57,64 meter dan debit andalan 83 liter/detik. Potensi selanjutnya disusul pada sungai Indabri sebesar 26,4 dengan net head 52,52 meter dan debit andalan 75 liter/detik, Demaisi sebesar 22,1 kW dengan net head 99,93 meter dan debit andalan 33 liter/detik, Hingk sebesar 12,7 kW dengan net head 9,44 meter dan debit andalan 200 liter/detik, Sururey sebesar 9,7 kW dengan net head 14,64 meter dan debit andalan 99 liter/detik dan terakhir Sungai Kopo sebesar 5,9 kW dengan net head 34,94 meter dan debit andalan 25 liter/detik.

Kata Kunci: PLTMH, Debit, Head, Pegunungan Arfak.

\section{Abstract}

The micro-hydro power plant (MHP) is a sustainable and environmentally friendly power plant. This study examines the potential of micro-hydro power plants by examining the dependable flow and head of several rivers in three districts: Minyambouw, Hingk and Sururey, in the Pegunungan Arfak Regency. The result is indicated the largest power potential in the Inggemou River Minyambouw District $32.1 \mathrm{~kW}$ with a net head of $57.64 \mathrm{~m}$ and a dependable flow of 83 liters/second, followed by the Indabri River by $26.4 \mathrm{~kW}$ with a net head of $52.52 \mathrm{~m}$ and a dependable flow of 75 liters/second, Demaisi of $22.1 \mathrm{~kW}$ with a net head of $99.93 \mathrm{~m}$ and a dependable flow of 33 liters/second, and Hingk by 12,7 kW with $9.44 \mathrm{~m}$ net head and dependable flow of 200 liters/second, Sururey 9.7 $\mathrm{kW}$ with $14.64 \mathrm{~m}$ net head and dependable flow 99 liters/second and lastly Kopo River by $5.9 \mathrm{~kW}$ with 34.94 net head $m$ and dependable flow of 25 liters/second.

Keywords: $\quad$ MHP, Dependable Flow, Head, Pegunungan Arfak. 


\section{Pendahuluan}

Energi Baru Terbarukan (EBT) adalah sumber-sumber energi yang terus menerus dibaharui oleh alam dan berasal langsung dari matahari (seperti termal, foto-kimia, dan fotolistrik), secara tidak langsung dari matahari (seperti angin, tenaga air, dan energi fotosintesis yang tersimpan di biomassa), atau dari gerakan dan mekanisme alami lingkungan lainnya (seperti energi panas bumi dan pasang surut) (Ellabban et al., 2014). Menurut PP No. 79 Tahun 2014 tentang Kebijakan Energi Nasional, pada tahun 2025 pasokan energi nasional ditargetkan sebesar 23\% dari EBT dan $31 \%$ pada 2050. Pemanfaatan EBT khususnya untuk pembangkit listrik masih minim di mana pada tahun 2018 hanya $14 \%$ dari total kapasitas pembangkit listrik. Minimnya pemanfaatan ini disebabkan harga produksi pembangkit berbasis EBT yang relatif masih tinggi (Dewan Energi Nasional, 2019).

Pembangkit listrik berbasis EBT yang bisa bersaing dengan pembangkit berbasis energi fosil adalah pembangkit tenaga air (Pusat Data dan Teknologi Informasi ESDM, 2017). Akan tetapi pembangkit jenis ini ketersediaan sumber dayanya bergantung pada wilayah. Ketersediaan sumber daya yang dimaksud adalah adanya sungai yang memiliki kapasitas debit air dan beda ketinggian (head) aliran. Semakin besar debit aliran maupun head maka semakin besar kapasitas energi yang bisa dimanfaatkan untuk menghasilkan energi listrik. Kapasitas pembangkit umumnya diklasifikasikan untuk digunakan sebagai dasar kebijakan pemerintah. Kapasitas sampai 100 kW diklasifikasikan sebagai mikrohidro (PLTMH), antara $100 \mathrm{~kW}$ hingga $1 \mathrm{MW}$ adalah minihidro (PLTM), $1 \mathrm{MW}$ hingga $10 \mathrm{MW}$ PLTA

Tabel 1.

Distribusi Penduduk Menurut Distrik dan Luas Wilayah

\begin{tabular}{|c|c|c|c|c|c|c|}
\hline No & Distrik & $\begin{array}{l}\text { Luas Wilayah } \\
\qquad\left(\mathbf{k m}^{2}\right)\end{array}$ & $\begin{array}{l}\text { Jumlah } \\
\text { Penduduk } \\
\text { (ribu jiwa) }\end{array}$ & $\begin{array}{c}\text { Jumlah } \\
\text { Rumah Tangga }\end{array}$ & $\begin{array}{l}\text { Kepadatan } \\
\text { Penduduk } \\
\left(\text { jiwa } / \mathbf{k m}^{2} \text { ) }\right.\end{array}$ & Jumlah Desa \\
\hline 1 & Didohu & 176,06 & 1.718 & 438 & 9,76 & 12 \\
\hline 2 & Sururey & 403,16 & 3.072 & 878 & 7,62 & 14 \\
\hline 3 & Anggi Gida & 191,56 & 1.565 & 272 & 8,17 & 13 \\
\hline 4 & Membey & 57,45 & 1.298 & 205 & 22,59 & 11 \\
\hline 5 & Anggi & 256,79 & 2.522 & 452 & 9,71 & 8 \\
\hline 6 & Taige & 112,12 & 1.583 & 281 & 14,12 & 6 \\
\hline 7 & Hingk & 367,22 & 6.828 & 1.650 & 18,59 & 37 \\
\hline 8 & Minyambouw & 192,58 & 5.808 & 1.310 & 30,16 & 29 \\
\hline 9 & Catubouw & 367,07 & 2.346 & 442 & 6,39 & 21 \\
\hline 10 & Testega & 493,34 & 919 & 190 & 1,86 & 15 \\
\hline & Jumlah & $2.617,35$ & 27.659 & 6.118 & 10,57 & 166 \\
\hline
\end{tabular}


kecil, 10 MW hingga $100 \mathrm{MW}$ adalah PLTA Sedang dan lebih besar dari $100 \mathrm{MW}$ adalah PLTA Besar (Pandey \& Karki, 2016).

Kabupaten Pegunungan Arfak yang berdiri tahun 2012 terdiri dari 10 distrik/kecamatan, terletak di bawah garis khatulistiwa antara $0^{\circ}$ $55^{\prime}$ LS hingga $1^{\circ} 40^{\prime} \mathrm{LS}$ dan $133^{\circ} 10^{\prime} \mathrm{BT}$ hingga $134^{\circ} 05^{\prime}$ BT. Penduduknya pada 2017 sebanyak 27.659 jiwa terdiri atas 13.757 jiwa penduduk laki-laki dan 13.902 jiwa penduduk perempuan dengan kepadatan penduduk mencapai 10,57 jiwa $/ \mathrm{km}^{2}$. Kepadatan penduduk terbesar terdapat di Distrik Minyambouw sebesar 30,16 jiwa $/ \mathrm{km}^{2}$ sedangkan yang terkecil di Distrik Testega sebesar $1,86 \mathrm{jiwa} / \mathrm{km}^{2}$ dari sepuluh distrik seperti yang ditunjukkan pada Tabel 1 (BPS Kabupaten Manokwari, 2018). Luasnya wilayah Kabupaten Pegunungan Arfak dengan sebaran pemukiman yang tidak merata menjadi tantangan dalam pendistribusian energi listrik di mana saat ini layanan 24 jam baru bisa dinikmati di ibu kota kabupaten dan disuplai oleh pembangkit listrik tenaga diesel.

Wilayah Kabupaten Pegunungan Arfak yang berada di pegunungan dan dengan adanya sungai membuka peluang pengembangan pembangkit listrik tenaga air khususnya skala mikrohidro untuk memenuhi kebutuhan penduduk akan energi listrik. Akan tetapi pemanfaatan potensi sering kali dibatasi oleh ketersediaan data karena terbatasnya studi dan penelitian terkait. Pasalli \& Rehiara (2014) telah melakukan studi perencanaan desain PLTMH di sungai Hingk dengan potensi maksimal 25,2 kW dengan head 8,6 meter dan debit air $0,3 \mathrm{~m}^{3} /$ detik dan produksi energi listrik 17,32 kW. Tulisan ini menyajikan hasil studi potensi PLTMH khususnya di tiga distrik di Kabupaten Pegunungan Arfak yaitu distrik Minyambouw, Hingk dan Sururey yang dapat ditindaklanjuti pada penelitian selanjutnya yaitu studi kelayakan dan perencanaan.

\section{Metode}

\section{A. Lokasi dan Waktu Penelitian}

Penelitian dilaksanakan pada bulan Agustus 2019 di Kabupaten Pegunungan Arfak pada tiga Distrik Minyambouw, Hingk dan Sururey. Penentuan lokasi penelitian ini didasarkan atas pertimbangan bahwa daerah tersebut belum dialiri oleh listrik dan diduga memiliki potensi sungai yang baik untuk PLTMH serta masukan dari pemerintah daerah dan PT. PLN Cabang Manokwari.

\section{B. Data dan Analisis Data}

\section{1) Geologi dan Hidrologi \\ Survei geologi dilakukan dengan} pendekatan geologi regional Lembar Ransiki (Pieters, 1990) dan Lembar Steenkol (Robinson, 1990). Untuk analisis hidrologi dan kemiringan lereng dilakukan dengan menggunakan citra satelit, Digital Elevation Model (DEM) dan Peta Rupa Bumi Indonesia (RBI) dan aplikasi Sistem Informasi Geografis (SIG) serta pengukuran di lapangan untuk penentuan debit lapangan yang nantinya akan menjadi perbandingan dengan hasil perhitungan debit andalan. Hasil pengukuran luas penampang basah sungai dengan meteran dan kecepatan aliran sungai dengan current meter di lapangan dianalisis untuk menghitung debit aliran dengan menggunakan rumus (1).

$$
Q=A \times v
$$

dengan $Q=$ Debit $\left(\mathrm{m}^{3} /\right.$ det $), A=$ Luas Penampang Sungai $\left(\mathrm{m}^{2}\right), v=$ kecepatan aliran (m/dt).

Lokasi pengukuran dipilih dengan memperhatikan kondisi aliran air yang tidak menyebar pada sungai tersebut. Pengukuran debit dilakukan dengan membagi penampang sungai menjadi beberapa segmen titik pengukuran kecepatan aliran di mana satu 
segmen titik dilakukan 1-3 kali pengukuran sesuai dengan kedalaman sungainya, sehingga didapatkan data kecepatan aliran air, serta panjang penampang sungai tiap segmen dan kedalaman pengukuran pada tiap titik.

Perhitungan potensi head dilakukan dengan menggunakan Digital Elevation Model serta aplikasi Sistem Informasi Geografis (SIG). Titik pengukuran debit merupakan lokasi 1 , sedangkan titik 2 merupakan lokasi yang direncanakan untuk pembangunan turbin. Titik-titik tersebut diambil koordinatnya dengan menggunakan GPS dan dimasukkan dalam aplikasi SIG, kemudian nilai ketinggian pada lokasi tersebut diambil dari data DEM.

\section{2) Perhitungan Debit Andalan Berdasarkan Metode Mock}

Perhitungan debit air pada DAS menggunakan metode FJ. Mock memerlukan data rata-rata curah hujan, data evapotranspirasi potensial dan data jumlah harian hujan. Data evapotranspirasi potensial dihitung dengan menggunakan metode Pennman Modifikasi yang mengacu pada Pratama (2016) dan Nugroho et al. (2017). Perhitungan metode Mock mengikuti prosedur sebagai berikut (Direktorat Jenderal Listrik dan Pemanfaatan Energi, 2009; Hadisusanto, 2010; Pratama, 2016):

- Menghitung evaporasi terbatas (Ee) dengan rumus:

$$
E e=\left(\frac{m}{20}\right) \times(18-n) \times E t 0
$$

dengan $m$ adalah permukaan lahan yang terbuka, $n$ adalah hari hujan dan EtO adalah evapotranspirasi potensial.

- Menghitung evapotranspirasi aktual (Ea) dengan rumus:

$$
E a=E t 0-E e
$$

- Menghitung keseimbangan air $(\Delta S)$ dengan rumus:

$$
\triangle S=R-E_{a}
$$

dengan $R$ adalah curah hujan bulanan (mm).

- Menghitung Limpasan Badai $(P F=5 \%)$ dengan ketentuan:

Jika $\Delta S \geq 0$, maka $P F=0$; Jika $\Delta S \leq 0, R \times 0.05$

- Menghitung kandungan air tanah (SS) dengan ketentuan:

Jika $R>E_{a}$ maka, $S S=0$; Jika $R<E_{a}$ maka, $S S$ $=\Delta S-P F$

- Menghitung kapasitas kelembapan tanah

Jika $S S=0$ maka kapasitas kelembapan air tanah $=200$

Jika $S S \neq 0$ maka kapasitas kelembapan air tanah $=$ kandungan air tanah

- Menghitung kelebihan air (WS) dengan rumus:

$$
W S=\triangle S-S S
$$

- Menghitung infiltrasi $(I)$ dengan rumus:

$I=i-W S$

dengan $i$ adalah faktor infiltrasi.

- Menghitung volume air tanah $(G)$ dengan rumus:

$$
G=0,5(1+k) \times I
$$

dengan $k$ adalah faktor resesi air tanah. 
- Menghitung penyimpanan volume air tanah awal terkoreksi $(L)$ dengan rumus:

$$
L=k\left(V_{n-1}\right)
$$

- Menghitung total volume penyimpanan air tanah $(V n)$ dengan rumus:

$$
V_{n}=[0,50(1+k) x I]+k\left(V_{n-1}\right)
$$

- Menghitung aliran dasar $(B F)$ dengan rumus:

$$
B F=I-\triangle V_{n}
$$

- Menghitung limpasan langsung (DR) dengan rumus:

$$
D R=W S-I+P F
$$

- Menghitung total limpasan (TRo) dengan rumus:

$$
T R o=B F+D R
$$

- Menghitung debit sungai pada bulan ke $n$ $(Q n)$ dengan rumus:

$$
Q n=T R o \times A / n
$$

dengan $A$ adalah luas DAS dan $n$ adalah jumlah hari bulan.

Hasil perhitungan debit setiap bulan selama beberapa tahun kemudian disusun dan ditentukan tingkat keandalannya yang dipilih berdasarkan probabilitas kejadian mengikuti rumus Weibull dan membentuk kurva yang dinamakan Flow Duration Curve (FDC).

$$
P=\frac{i}{n+1} \times 100 \%
$$

dengan $i$ adalah nomor urut debit dengan urutan kejadian dari besar ke kecil, $n$ adalah jumlah data dan $P$ adalah probabilitas terjadinya kumpulan nilai yang diharapkan selama periode pengamatan (\%). Dalam kajian ini dipilih debit andalan dengan persentase 80\% - 96\% (Kusumastuti et al., 2016).

\section{3) Perhitungan Daya}

Menurut Tobi \& van Harling (2017), potensi hidrolik adalah potensi energi yang ditimbulkan oleh tekanan air akibat gravitas bumi. Potensi energi mikrohidro yang tersedia di alam merupakan potensi hidrolik dalam bentuk energi potensial yang besarnya dipengaruhi oleh besarnya debit dan ketinggian/head. Untuk mendapatkan daya hidrolik $\left(P_{h}\right)$ yang merupakan potensi sumber daya energi air digunakan persamaan (15):

Potensi hidrolik $\left(P_{h}\right)$ :

$$
P_{h}=Q \times H \times g
$$

Energi dalam bentuk potensi hidrolik tidak semuanya dikonversi menjadi tenaga listrik. Pada saat konversi dari energi potensial menjadi energi listrik, sebagian energi akan hilang dalam bentuk losses. Potensi daya listrik (PLTMH) yang dapat dibangkitkan berdasarkan hasil perhitungan potensi hidrolik tersebut dapat dihitung dengan persamaan (16).

Kapasitas daya pembangkit $\left(P_{e}\right)$ :

$$
P_{e}=\eta_{T} \times \eta_{G} \times \eta_{M} \times P_{h}
$$

dengan $P_{h}$ adalah potensi hidrolik (kW), Pe adalah potensi daya listrik $(\mathrm{kW}), \eta_{T}$ adalah efisiensi turbin $(0,8-0,95), \eta_{G}$ adalah efisiensi generator $(0,8-0,95), \quad \eta_{M}$ adalah efisiensi transmisi mekanik $(0,95$ untuk $V$ belt atau 0,98 untuk flat belt $), g$ adalah gaya gravitasi $(9,8 \mathrm{~m} /$ $\left.\mathrm{dt}^{2}\right), Q$ adalah debit andalan $\left(\mathrm{m}^{3} / \mathrm{dt}\right)$ dan $H$ adalah tinggi efektif (m) (Nugroho et al., 2017). 


\section{Hasil dan Pembahasan}

\section{A. Geologi dan Hidrologi}

\section{1) Geologi Daerah Survei}

Titik stasiun data Survei energi terbarukan di Kabupaten Pegunungan Arfak masuk dalam 2 (dua) satuan fisiografis regional, yaitu:

- Pegunungan Bagian Tengah Kepala Burung

Satuan fisiografis ini dibatasi oleh singkapan Formasi Kemum, di mana topografi di bagian barat dan tengah satuan ini seragam dengan puncak sampai beberapa ratus meter. Topografi itu dicirikan oleh punggungan pendek atau perbukitan dan pegunungan berlereng curam dan puncak yang luas. Ketinggian rata-rata berangsur menurun dari lebih 1600 m dpl sekitar Sungai Wariori sampai sekitar 800 mdpl di bagian barat. Makin jauh ke timur pegunungan lebih kasar dengan ketinggian menjulang sekitar 2800 mdpl. Kampung di Distrik Minyambouw dan Distrik Hingk masuk dalam satuan fisiografis ini.

- Pelataran antar Gunung Anggi

Terdapat pada hulu cabang Sungai Wariori yang berarah tenggara dan Sungai Ransiki di mana keduanya menyuplai Danau Anggi Gigi (pada ketinggian sekitar $1700 \mathrm{~m} \mathrm{dpl)}$ dan Danau Anggi Gida (1660 mdpl), di mana kedua danau tersebut memiliki daerah tangkapan yang kecil. Danau Anggi Gigi tersalurkan pada bagian utara melalui Sungai Ngemona dan masuk ke Sungai Wariori, sedangkan Danau Anggi Gida tersalurkan pada bagian timur masuk ke Sungai Ransiki. Permukaan danau tersebut dicirikan oleh perbukitan dan lembah yang

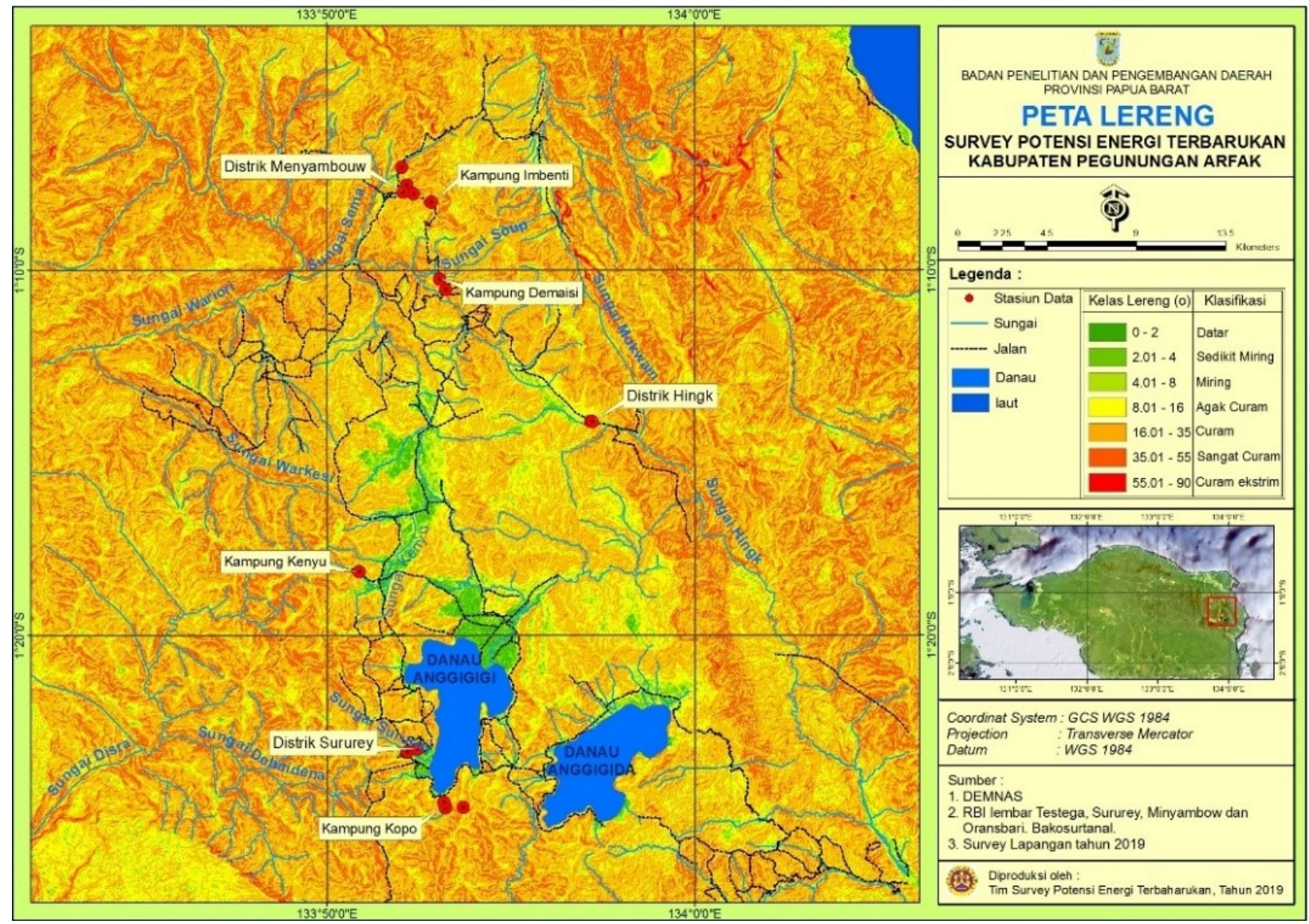

Gambar 1. Peta Hasil Analisis Lereng Daerah Survei 
lebar dengan dataran yang ditempati oleh sungai berkelok-kelok seperti Sungai Ngemona dan Sungai Irai. Danau tersebut dikelilingi oleh daerah pegunungan dengan ketinggian dari $2500-2800 \mathrm{mdpl}$ pada bagian timur. Kampung di Distrik Sururey dan Kampung Kopo masuk dalam satuan fisiografis ini.

Dilihat dari morfologi hasil analisis kemiringan lereng daerah Survei energi terbarukan (Gambar 1), Daerah Distrik Minyambouw yang terdiri atas Kampung Handuk, Kampung Minyambouw, Kampung Mbenti dan Kampung Demaisi dan Distrik Hingk serta daerah Sungai Sururey dan Sungai Kopo masuk dalam satuan Pegunungan bagian tengah Kepala Burung dengan kemiringan lereng dalam klasifikasi Van Zuidam, 1985 merupakan daerah dengan morfologi agak curam hingga sangat curam dengan kemiringan lereng $8^{\circ}-55^{\circ}$. Sedangkan Kampung di Distrik Sururey dan Kampung Kopo masuk dalam satuan fisiografis Pelataran antar Gunung Anggi dengan datar hingga miring dengan kemiringan lereng $0^{\circ}-8^{\circ}$.

Daerah survei potensi energi terbarukan di Kabupaten Pegunungan Arfak terdiri atas berbagai variasi litologi pada tiap formasi batuan (Gambar 2), yaitu:

- Kampung Kopo, Distrik Sururey dan Distrik Hingk terdapat pada Formasi Aluvium (Ql) berupa bahan rombakan

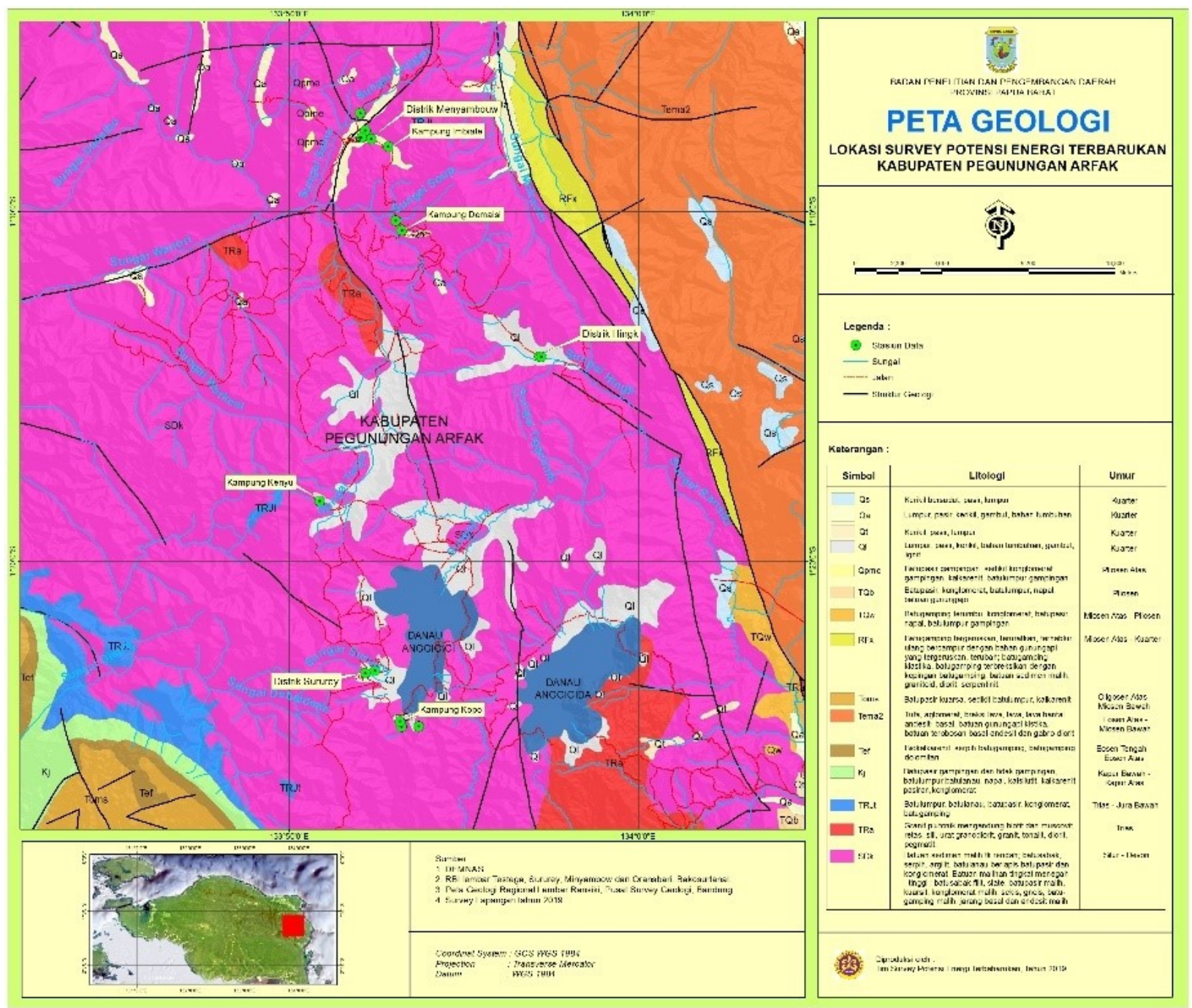

Gambar 2. Peta Geologi Regional Daerah Survei 


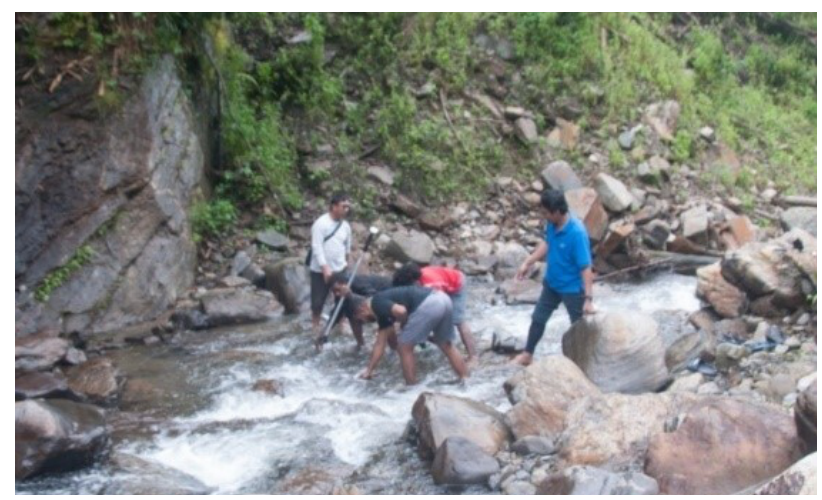

Gambar 3. Kiri: Sungai Inggemou; Kanan: Sungai Demaisi

lumpur, pasir, kerikil, bahan tumbuhan, gambut dan lignit. Sedangkan sungaisungai pada daerah tersebut berupa Sungai Kopo, Sungai Sururey dan Sungai Hingk juga melewati Formasi Kemum (SDk)

- Kampung Demaisi dan kampung-kampung di Distrik Minyambouw terdapat pada Formasi Aluvium (Qa) berupa bahan rombakan pasir, kerikil, gambut dan bahan tumbuhan. Sedangkan sungai-sungai pada daerah tersebut berupa Sungai Soup, Sungai Indabri, Sungai Mbenti dan Sungai Meteibe juga melewati Formasi Kemum (SDk).

\section{2) Hidrologi Daerah Survei}

Sungai-sungai di Kabupaten Pegunungan Arfak umumnya membentuk pola aliran dendritik dengan cabang sungai menyerupai ranting pohon yang mengalir ke sungai utama dan pola rektangular dengan cabang sungai membentuk sudut $90^{\circ}$ akibat kontrol struktur geologi. Sebagian besar anak sungai yang mengalir ke sungai utama berjenis sungai permanen atau mengalir sepanjang tahun yang menyuplai air ke sungai utama.

Dari hasil analisis hidrologi, sungai-sungai yang terdapat di Kabupaten Pegunungan Arfak yang berpotensi untuk PLTMH adalah Sungai Soup di Kampung Demaisi dengan luas DAS 6,2 $\mathrm{km}^{2}$, Sungai Hingk dengan luas DAS $12,9 \mathrm{~km}^{2}$, Sungai Sururey dengan luas DAS $77,87 \mathrm{~km}^{2}$, Sungai Kopo dengan luas DAS $1,8 \mathrm{~km}^{2}$, Sungai

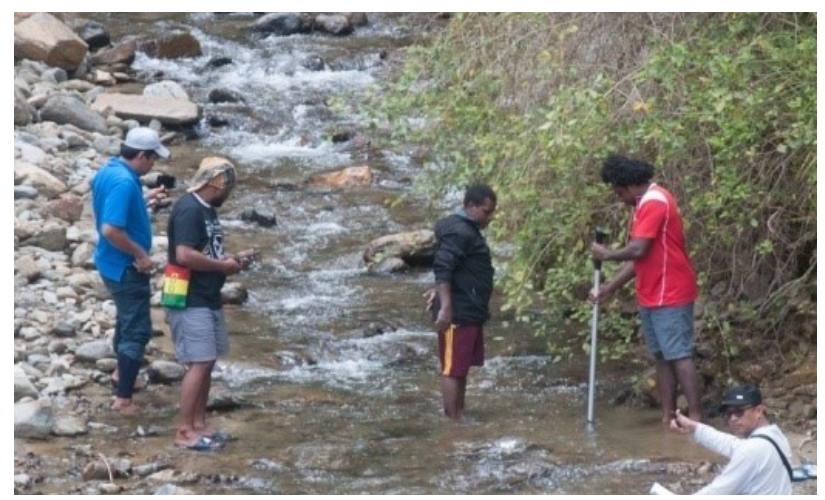

Indabri di Kampung Handuk dengan luas DAS $8,5 \mathrm{~km}^{2}$, Sungai Inggemou dengan luas DAS $14,8 \mathrm{~km}^{2}$.

\section{B. Perhitungan Debit Air}

Pengukuran debit air di Kabupaten Pegunungan Arfak dilakukan di enam sungai, yaitu Sungai Kopo di Kampung Kopo, Sungai Sururey di Kampung Sururey, Sungai Hingk di Kampung Hingk, Sungai Soup di Kampung Demaisi, Sungai Indabri di Kampung Handuk dan Sungai Inggemou di Kampung Minyambouw. Dokumentasi pengukuran dan hasil debit pengukuran lapangan ditunjukkan pada Gambar 3 dan Tabel 2.

\section{Simulasi Debit Andalan}

Perhitungan debit andalan dilakukan dengan menggunakan data suhu, kelembapan, kecepatan angin, penyinaran matahari dan curah hujan selama tiga tahun mulai tahun 2015 hingga tahun 2017 yang bersumber dari Badan Meteorologi, Klimatologi dan Geofisika (BMKG) Manokwari. Idealnya perhitungan debit andalan dilakukan dengan menggunakan data selama 10 tahun, akan tetapi karena ketersediaan data yang sangat minim, perhitungan hanya dilakukan dengan menggunakan data selama 3 tahun. Pada Tabel 3 dan Tabel 4 ditunjukkan contoh hasil perhitungan evapotranspirasi potensial dan debit bulanan di Sungai Sururey pada tahun 2015.

Hasil simulasi kurva debit untuk masingmasing sungai ditunjukkan pada Gambar 5 - 


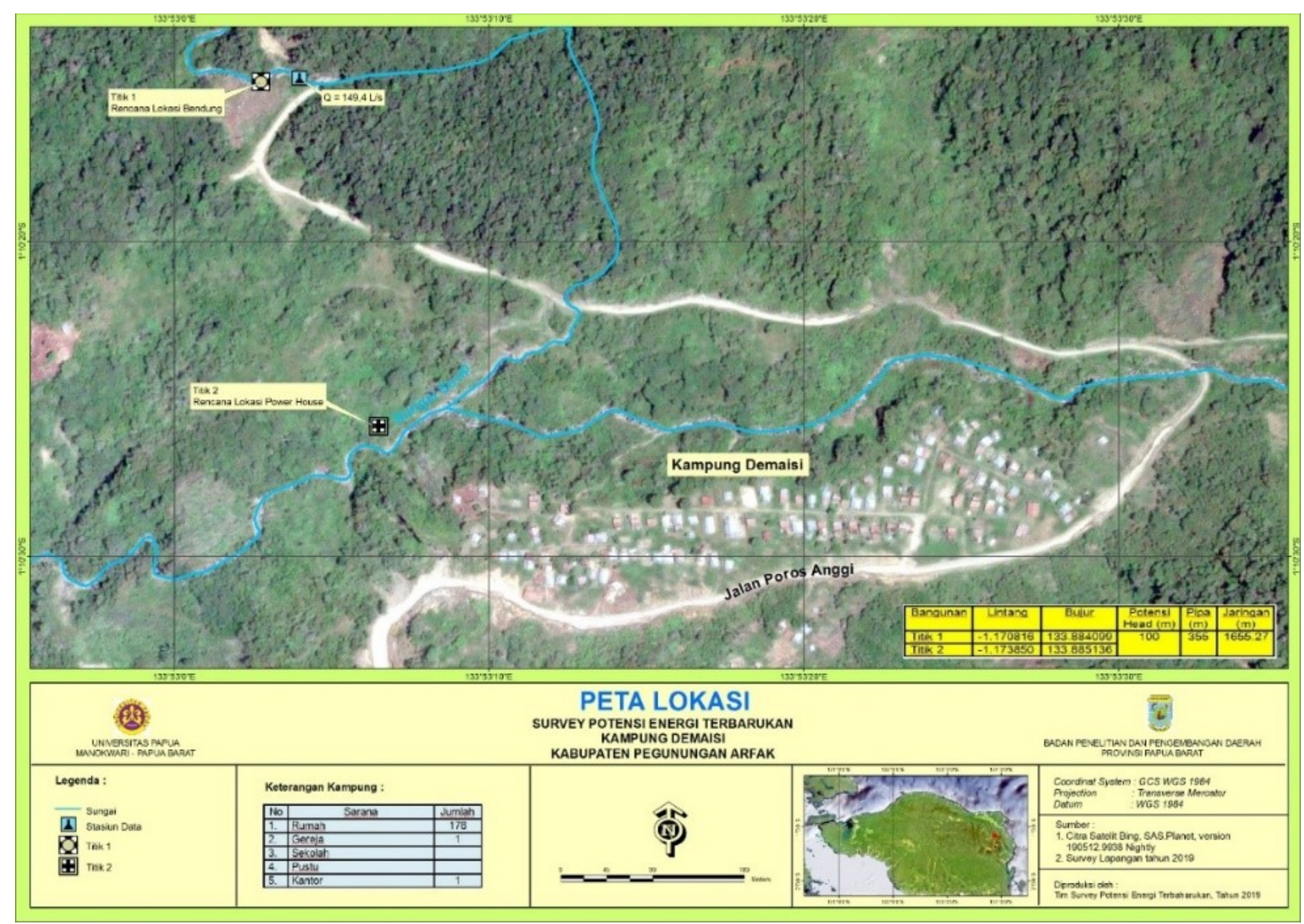

Gambar 4. Salah Satu Peta Lokasi Survei Potensi PLTMH di Kampung Demaisi

Tabel 2.

Hasil Pengukuran debit beberapa lokasi di Kabupaten Pegunungan Arfak

\begin{tabular}{|c|c|c|c|c|c|c|}
\hline \multirow{2}{*}{ No. } & \multirow{2}{*}{ Sungai/Kampung } & \multirow{2}{*}{ Titik Data } & \multicolumn{2}{|c|}{ Lokasi } & \multirow{2}{*}{ Debit (L/dt) } & \multirow{2}{*}{ Potensi Head (m) } \\
\hline & & & Lintang & Bujur & & \\
\hline \multirow{2}{*}{1} & \multirow{2}{*}{ Коро/Коро } & Titik 1 & -1.411861 & 133.887 & \multirow{2}{*}{26,8} & \multirow{2}{*}{35} \\
\hline & & Titik 2 & -1.408144 & 133.884201 & & \\
\hline \multirow{2}{*}{2} & \multirow{2}{*}{ Sururey/Sururey } & Titik 1 & -1.385611 & 133.867746 & \multirow{2}{*}{97} & \multirow{2}{*}{15} \\
\hline & & Titik 2 & -1.386803 & 133.869737 & & \\
\hline \multirow{3}{*}{3} & \multirow{3}{*}{ Hingk/Hingk } & Titik 1 & -1.235667 & 133.952917 & \multirow{3}{*}{420} & \multirow{3}{*}{10} \\
\hline & & & & & & \\
\hline & & Titik 2 & -1.235889 & 133.953806 & & \\
\hline \multirow{2}{*}{4} & \multirow{2}{*}{ Soup/Demaisi } & Titik 1 & -1.170816 & 133.884099 & \multirow{2}{*}{149} & \multirow{2}{*}{100} \\
\hline & & Titik 2 & -1.17385 & 133.885136 & & \\
\hline \multirow{2}{*}{5} & \multirow[b]{2}{*}{ Sungai Indabri } & Titik 1 & -1.110462 & 133.878471 & \multirow[b]{2}{*}{217} & \multirow[b]{2}{*}{53} \\
\hline & & Titik 2 & 1113394 & 133.87423 & & \\
\hline \multirow{3}{*}{6} & \multirow{3}{*}{ Inggemou/ Minyambouw } & Titik 1 & -1.127585 & 133.869912 & 310 & \multirow{2}{*}{58} \\
\hline & & Titik 2 & -1.13028 & 133.868166 & 234 & \\
\hline & & Titik 3 & -1.13024 & 133.869522 & 377 & 35 \\
\hline
\end{tabular}

Potensi Pembangkit Listrik Tenaga Mikrohidro (PLTMH)

di Kabupaten Pegunungan Arfak 
Tabel 3.

Contoh Perhitungan Evapotranspirasi Potensial di Sungai Sururey pada 2015

\begin{tabular}{|c|c|c|c|c|c|c|c|c|c|c|c|c|}
\hline \multirow{2}{*}{ URAIAN } & \multicolumn{12}{|c|}{ Tahun 2015} \\
\hline & JAN & FEB & MAR & APR & MEI & JUN & JUL & AGUS & SEP & ОКт & NOP & DES \\
\hline Temperatur Udara ( $\mathrm{T}$ ) & 27.5 & 26.6 & 26.8 & 27.1 & 27.6 & 27.4 & 27.3 & 27 & 28.2 & 28.2 & 28.1 & 24.8 \\
\hline Ea (ea) & 34.8 & 33.453 & 34.04 & 34.99 & 36.193 & 34.8 & 34.42 & 35.982 & 37.459 & 37.897 & 35.982 & 35.56 \\
\hline w & 0.7563 & 0.749 & 0.752 & 0.7574 & 0.7637 & 0.7563 & 0.7542 & 0.7627 & 0.7692 & 0.7707 & 0.7627 & 0.7606 \\
\hline $1-W$ & 0.2437 & 0.251 & 0.248 & 0.2426 & 0.2363 & 0.2437 & 0.2458 & 0.2373 & 0.2308 & 0.2293 & 0.2373 & 0.2394 \\
\hline$f(T)$ & 16.02 & 15.875 & 15.94 & 16.04 & 16.16 & 16.02 & 15.98 & 16.14 & 16.28 & 16.32 & 16.14 & 16.1 \\
\hline Kelembapan Relatif (RH) & 0.82 & 0.83 & 0.83 & 0.83 & 0.84 & 0.85 & 0.83 & 0.78 & 0.81 & 0.79 & 0.82 & 0.85 \\
\hline$E d=e a \times R H$ & 28.536 & 27.76599 & 28.2532 & 29.0417 & 30.40212 & 29.58 & 28.5686 & 28.06596 & 30.34179 & 29.93863 & 29.50524 & 30.226 \\
\hline Perbedaan ed dan ea & 6.264 & 5.68701 & 5.7868 & 5.9483 & 5.79088 & 5.22 & 5.8514 & 7.91604 & 7.11721 & 7.95837 & 6.47676 & 5.334 \\
\hline akar ed & 2.502798 & 2.384745 & 2.405577 & 2.438914 & 2.406425 & 2.284732 & 2.418967 & 2.813546 & 2.66781 & 2.821058 & 2.544948 & 2.309545 \\
\hline$F(e d)=0.34-0.044$ akar ed & 0.229877 & 0.235071 & 0.234155 & 0.232688 & 0.234117 & 0.239472 & 0.233565 & 0.216204 & 0.222616 & 0.215873 & 0.228022 & 0.23838 \\
\hline Letak Lintang daerah & $1.8^{\circ} \mathrm{LS}$ & $1.8^{\circ} \mathrm{LS}$ & $1.8^{\circ} \mathrm{LS}$ & $1.8^{\circ} \mathrm{LS}$ & $1.8^{\circ} \mathrm{LS}$ & $1.8^{\circ} \mathrm{LS}$ & $1.8^{\circ} \mathrm{LS}$ & $1.8^{\circ} \mathrm{LS}$ & $1.8^{\circ} \mathrm{LS}$ & $1.8^{\circ} \mathrm{LS}$ & $1.8^{\circ} \mathrm{LS}$ & $1.8^{\circ} \mathrm{LS}$ \\
\hline Ra & 15.27 & 15.68 & 15.7 & 15.12 & 14.13 & 13.54 & 13.74 & 14.53 & 15.21 & 15.49 & 15.28 & 15.07 \\
\hline Penyinaran Matahari, $n / N$ & 43 & 44 & 53 & 58 & 66 & 58 & 69 & 76 & 84 & 88 & 55 & 44 \\
\hline$R s=(0,25+0.54 n / N) \cdot R a$ & 7.10055 & 7.3696 & 8.0855 & 8.1648 & 8.1954 & 7.3116 & 8.1753 & 9.1539 & 10.1907 & 10.6881 & 8.022 & 7.0829 \\
\hline Rns=(1-a)Rs, a=0.25 & 5.325413 & 5.5272 & 6.064125 & 6.1236 & 6.14655 & 5.4837 & 6.131475 & 6.865425 & 7.643025 & 8.016075 & 6.0165 & 5.334 \\
\hline$F(n / N)=0,1+0,9 n / N$ & 0.487 & 0.496 & 0.577 & 0.622 & 0.694 & 0.622 & 0.721 & 0.784 & 0.856 & 0.892 & 0.595 & 0.496 \\
\hline Kecepatan angin, u & 9.97936 & 10.69952 & 10.90528 & 8.53904 & 7.30448 & 7.61312 & 7.81888 & 10.08224 & 7.40736 & 7.716 & 8.12752 & 10.288 \\
\hline$F(u)=0,27(1+(u \cdot 0,864))$ & 2.597985 & 2.765984 & 2.813984 & 2.261987 & 1.973989 & 2.045989 & 2.093988 & 2.621985 & 1.997989 & 2.069988 & 2.165988 & 2.669985 \\
\hline$R n 1=f(t) \cdot f(e d) \cdot f(n / N)$ & 1.79344 & 1.850951 & 2.153609 & 2.321498 & 2.625635 & 2.386202 & 2.691043 & 2.735793 & 3.10231 & 3.142565 & 2.189766 & 1.903607 \\
\hline $\mathrm{Rn}=\mathrm{Rns}-\mathrm{Rn} 1$ & 3.531973 & 3.676249 & 3.910516 & 3.802102 & 3.520915 & 3.097498 & 3.440432 & 4.129632 & 4.540715 & 4.87351 & 3.826734 & 3.408568 \\
\hline Angka koreksi @ & 0.8963 & 0.8963 & 0.832 & 0.804 & 0.804 & 0.804 & 0.86 & 0.776 & 0.86 & 0.86 & 0.8963 & 0.86 \\
\hline Et0* & 6.637151 & 6.701786 & 6.97913 & 6.14389 & 5.3901 & 4.945368 & 5.606503 & 8.075007 & 6.774718 & 7.533442 & 6.247633 & 6.002019 \\
\hline Et0 $=c . E t 0^{*}$ & 4.55 & 4.41 & 4.63 & 4.63 & 4.54 & 4.14 & 4.61 & 5.52 & 5.65 & 6.02 & 4.89 & 3.82 \\
\hline $\begin{array}{l}\text { Jumlah hari dalam satu } \\
\text { bulan }\end{array}$ & 31 & 28 & 31 & 30 & 31 & 30 & 31 & 31 & 30 & 31 & 30 & 31 \\
\hline Hasil Akhir Eto & 141.05 & 123.48 & 143.53 & 138.9 & 140.74 & 124.2 & 142.91 & 171.12 & 169.5 & 186.62 & 146.7 & 118.42 \\
\hline
\end{tabular}

Gambar 10. Debit andalan terbesar dari ke enam sungai yang dikaji terdapat pada sungai Hingk di Kampung Hingk yaitu sebesar 200 $\mathrm{L} / \mathrm{dt}$.

Berdasarkan persamaan (15) dan (16) dengan data kurva debit masing-masing sungai dengan $\eta \mathrm{T}=0,8, \eta \mathrm{G}=0,9$, dan $\eta \mathrm{M}=0,95$, hasil perhitungan potensi PLTMH pada sungaisungai tersebut ditunjukkan pada Tabel 5 . Total potensi PLTMH pada sungai-sungai yang dikaji adalah 108,9 kW dengan potensi terbesar pada sungai Inggemou sebesar 32,1 $\mathrm{kW}$ dan potensi terkecil pada sungai Kopo sebesar 5,9 kW. Potensi head bervariasi dari 10 $\mathrm{m}$ hingga $100 \mathrm{~m}$ dengan variasi debit andalan dari $25 \mathrm{~L} / \mathrm{dt}$ hingga $200 \mathrm{~L} / \mathrm{dt}$.

Adanya perbedaan yang cukup besar pada debit pengukuran dan debit andalan di sungai Hingk, Demaisi, Indabri dan Inggemou disebabkan karena debit pengukuran hanya dilakukan sesaat di mana kemungkinannya terjadi hujan di DAS masing-masing sungai tersebut, sehingga nilainya berbeda dengan debit andalan yang merupakan debit dengan probabilitas kejadian 80\% - 96\%. 
Tabel 4.

Contoh Perhitungan Debit Bulanan di Sungai Sururey pada 2015

\begin{tabular}{|c|c|c|c|c|c|c|c|c|c|c|c|c|c|}
\hline \multirow{2}{*}{ URAIAN } & \multirow{2}{*}{ SAT } & \multicolumn{12}{|c|}{ TAHUN 2015} \\
\hline & & JAN & FEB & MAR & APR & MEI & JUN & JUL & AGUS & SEP & ОКт & NOP & DES \\
\hline Hujan Bulanan (R) & $\mathrm{mm} / \mathrm{bln}$ & 167.2 & 459.9 & 293.6 & 676 & 226.5 & 176.2 & 58.5 & 68.3 & 63.8 & 89 & 32.4 & 537.6 \\
\hline Hari hujan (n) & hari & 22 & 23 & 23 & 23 & 23 & 15 & 12 & 14 & 10 & 9 & 17 & 27 \\
\hline Evaporasi Potensial (Eto) & $\mathrm{mm} / \mathrm{bln}$ & 141.05 & 123.48 & 143.53 & 138.9 & 140.74 & 124.2 & 142.91 & 171.12 & 169.5 & 186.62 & 146.7 & 118.42 \\
\hline $\mathrm{Ea}=\mathrm{Eto}-\mathrm{Ee}$ & $\mathrm{mm} / \mathrm{bln}$ & 141.05 & 123.48 & 143.53 & 138.9 & 140.74 & 122.337 & 138.623 & 167.698 & 162.72 & 178.222 & 145.967 & 118.42 \\
\hline Kelebihan Air (WS= $\Delta S-S S$ ) & $\mathrm{mm} / \mathrm{bln}$ & 26.15 & 336.42 & 150.07 & 537.1 & 85.76 & 53.863 & 2.925 & 3.415 & 3.19 & 4.45 & 1.62 & 419.18 \\
\hline Infiltrasi (I=i×WS) & $\mathrm{mm} / \mathrm{bln}$ & 10.46 & 134.568 & 60.028 & 214.84 & 34.304 & 21.5452 & 1.17 & 1.366 & 1.276 & 1.78 & 0.648 & 167.672 \\
\hline Vol. Penyimpanan (Vn) & & 68.368 & 148.675 & 137.228 & 254.209 & 179.968 & 125.217 & 76.0663 & 46.7326 & 29.0603 & 18.8602 & 11.8345 & 141.238 \\
\hline Aliran Dasar (BF) & $\mathrm{mm} / \mathrm{bln}$ & 42.092 & 54.2608 & 71.4757 & 97.859 & 108.544 & 76.2964 & 50.3209 & 30.6997 & 18.9482 & 11.9801 & 7.67368 & 38.2682 \\
\hline Limpasan langsung (DR) & $\mathrm{mm} / \mathrm{bln}$ & 15.69 & 201.852 & 90.042 & 322.26 & 51.456 & 32.3178 & 4.68 & 5.464 & 5.104 & 7.12 & 2.592 & 251.508 \\
\hline Total Limpasan (Tro) & $\mathrm{mm} / \mathrm{bln}$ & 57.782 & 256.113 & 161.518 & 420.119 & 160 & 108.614 & 55.0009 & 36.1637 & 24.0522 & 19.1001 & 10.2657 & 289.776 \\
\hline Luas Daerah Tangkapan & $\mathrm{km}^{2}$ & 77.875 & 77.875 & 77.875 & 77.875 & 77.875 & 77.875 & 77.875 & 77.875 & 77.875 & 77.875 & 77.875 & 77.875 \\
\hline Jumlah hari dalam 1 bulan & hari & 31 & 28 & 31 & 30 & 31 & 30 & 31 & 31 & 30 & 31 & 30 & 31 \\
\hline Debit Bulanan & $\mathrm{L} / \mathrm{dt}$ & 1680.02 & 8244.37 & 4696.16 & 12622.2 & 4652.04 & 3263.24 & 1599.16 & 1051.47 & 722.634 & 555.34 & 308.426 & 8425.3 \\
\hline
\end{tabular}

Tabel 5.

Hasil Perhitungan Potensi PLTMH di Kabupaten Pegunungan Arfak

\begin{tabular}{|c|c|c|c|c|c|c|c|}
\hline No. & Sungai/ Kampung & $\begin{array}{l}\text { Debit } \\
\text { Pengukuran } \\
\text { (L/dt) }\end{array}$ & $\begin{array}{l}\text { Debit Andalan } \\
\text { (L/dt) }\end{array}$ & $\begin{array}{l}\text { Potensi Head } \\
\text { (m) }\end{array}$ & $\begin{array}{l}\text { Net } \\
\text { Head } \\
(\mathrm{m})\end{array}$ & $\begin{array}{c}\text { Potensi } \\
\text { Hidrolik } \\
\text { (kW) }\end{array}$ & $\begin{array}{l}\text { Daya PLTMH } \\
\text { (kW) }\end{array}$ \\
\hline 1 & Kopo & 27 & 25 & 35 & 34,94 & 8,6 & 5,9 \\
\hline 2 & Sururey & 97 & 99 & 15 & 14,64 & 14,2 & 9,7 \\
\hline 3 & Hingk & 420 & 200 & 10 & 9,44 & 18,5 & 12,7 \\
\hline 4 & Demaisi & 149 & 33 & 100 & 99,93 & 32,3 & 22,1 \\
\hline 5 & Indabri & 217 & 75 & 53 & 52,52 & 38,6 & 26,4 \\
\hline 6 & Inggemou & 307 & 83 & 58 & 57,64 & 46,9 & 32,1 \\
\hline
\end{tabular}




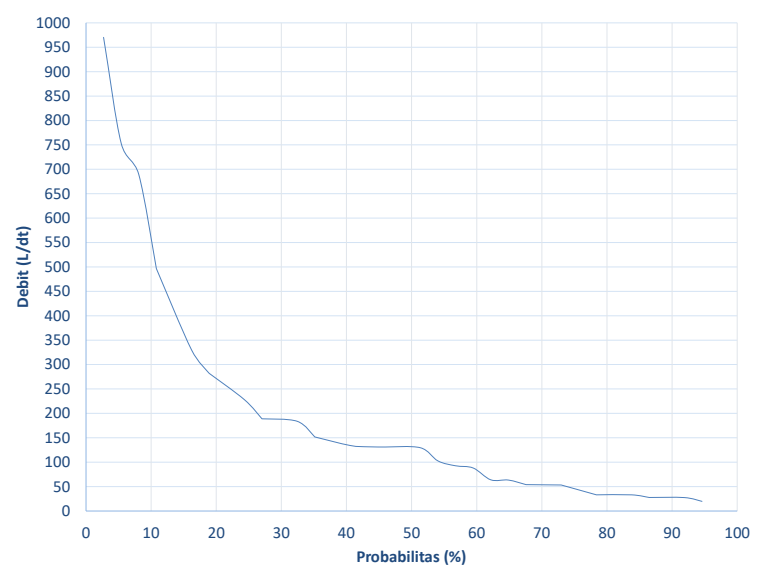

Gambar 5. FDC Sungai Soup di Kampung Demaisi

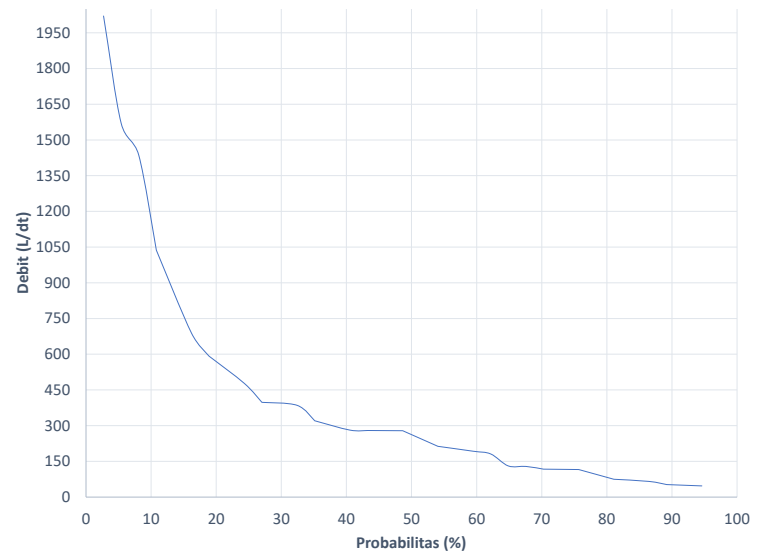

Gambar 6. FDC Sungai Indabri

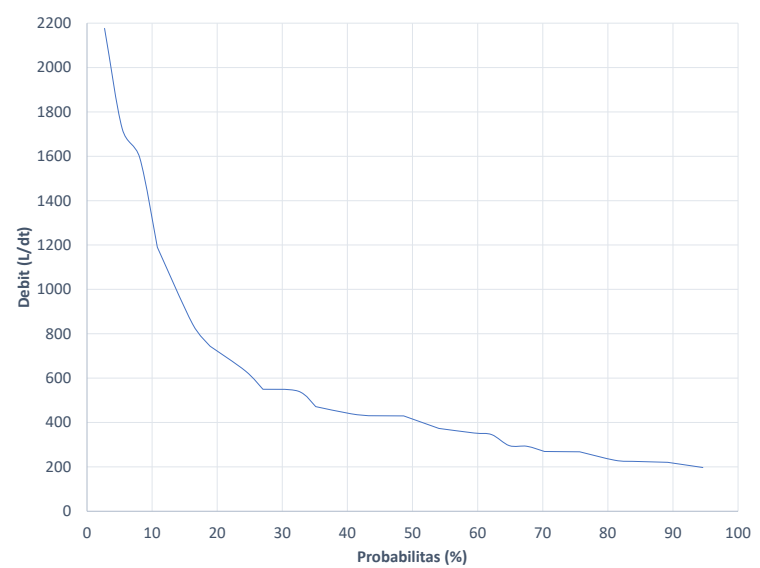

Gambar 7. FDC Sungai Hingk di Kampung Hingk

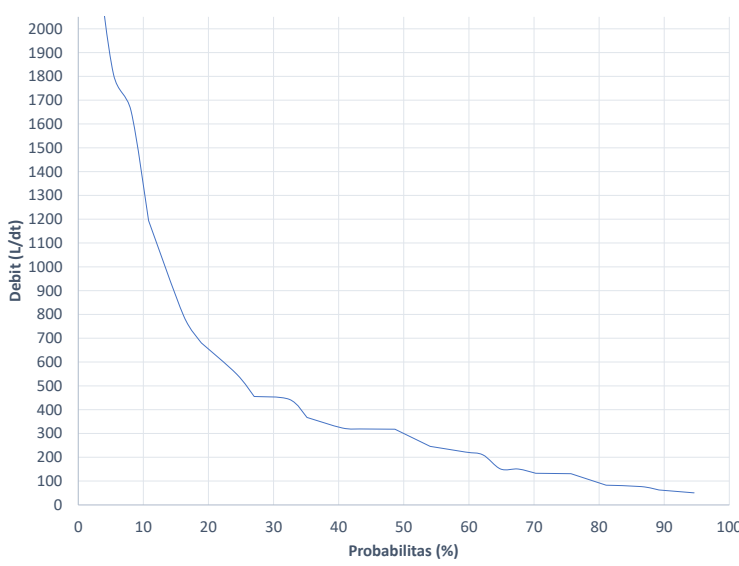

Gambar 8. FDC Sungai Inggemou di Kampung Minyambouw

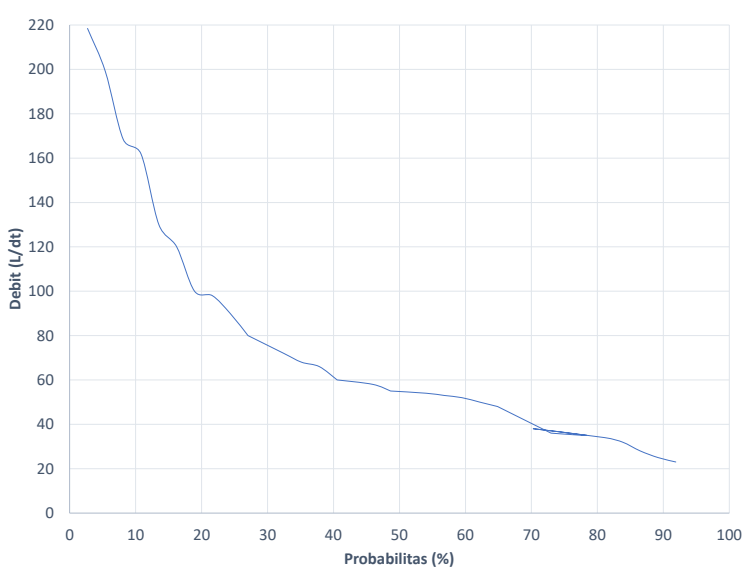

Gambar 9. FDC Sungai Kopo di Kampung Kopo

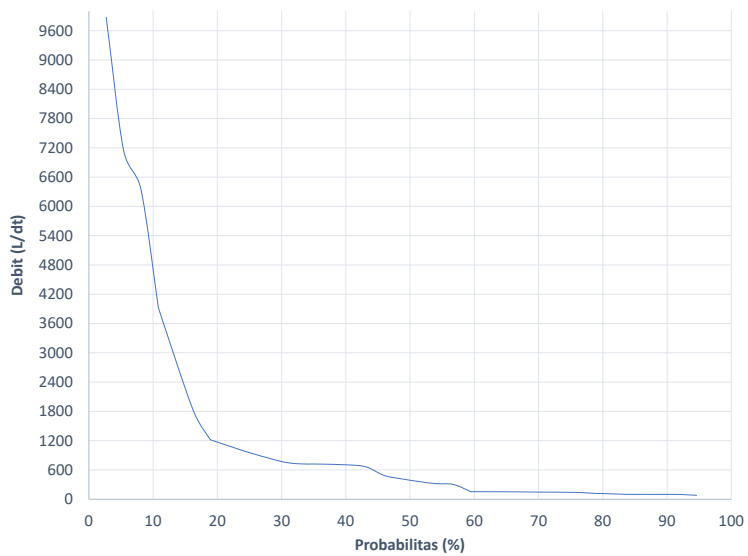

Gambar 10. FDC Sungai Sururey di Kampung Sururey FDC Sungai Sururey di Kampung Sururey 


\section{Kesimpulan}

Debit andalan yang terbesar terdapat pada sungai Hingk di Kampung Hingk yaitu sebesar $200 \mathrm{~L} / \mathrm{dt}$ dan debit yang terkecil terdapat pada sungai Kopo di Kampung Kopo. Total potensi PLTMH di tiga distrik yang dikaji adalah sebesar 108,9 kW dengan potensi yang terbesar berada pada sungai Inggemou sebesar $32,1 \mathrm{~kW}$ dan potensi yang terkecil sebesar 5,9 kW di Sungai Kopo. Pemanfaatan potensi PLTMH dapat memenuhi kebutuhan masyarakat akan energi listrik dan sekaligus mengurangi ketergantungan bahan bakar solar yang saat ini masih mendominasi wilayah Pegunungan Arfak.

\section{Ucapan Terima Kasih}

Penulis mengucapkan terima kasih kepada Balitbangda Provinsi Papua Barat, PT. PLN (Persero) Cabang Manokwari dan BAPEDA Kabupaten Pegunungan Arfak atas dukungan pada penelitian ini. Selain itu ucapan terima kasih juga diberikan kepada kepala kampung dan masyarakat di Kabupaten Pegunungan Arfak. Terima kasih juga kepada para editor anonim yang sudah me-review dan memberikan saran perbaikan naskah tulisan ini.

\section{Referensi}

BPS Kabupaten Manokwari. (2018). Kabupaten Pegunungan Arfak dalam Angka 2018. BPS

Kabupaten Manokwari.

Dewan Energi Nasional. (2019). Indonesia Energy Outlook 2019. Dewan Energi Nasional.

Direktorat Jenderal Listrik dan Pemanfaatan Energi. (2009). Pedoman Studi Kelayakan Hidrologi. Direktorat Jenderal Listrik dan Pemanfaatan Energi.

Ellabban, O., Abu-Rub, H., \& Blaabjerg, F. (2014). Renewable energy resources: Current status, future prospects and their enabling technology. Renewable and Sustainable Energy Reviews, 39, 748-764. h t tp s: / / doi.org / $10.1016 /$ j.rser.2014.07.113

Hadisusanto, N. (2010). Aplikasi Hidrologi. Jogja Mediautama.

Kusumastuti, D. I., Winarno, D. J., Humaidi, Falah, M. N., \& Robiyanto. (2016). Estimasi Potensi PLTMH dengan Metode Regionalisasi pada Ungauged Catchments di Kecamatan Suoh. Jurnal Teknik Sipil, 23(1), 63-74. https://doi.org/10.5614/ jts.2016.23.1.7

Nugroho, D., Suprajitno, A., \& Gunawan, G. (2017). Desain Pembangkit Listrik Tenaga Mikrohidro di Air Terjun Kedung Kayang. Jurnal Rekayasa Elektrika, 13(3), 161-171. https://doi.org/10.17529/jre.v13i3.8554

Pandey, B., \& Karki, A. (2016). Hydroelectric Energy: Renewable Energy and the Environment. CRC Press.

Pasalli, Y. R., \& Rehiara, A. B. (2014). Design Planning of Micro-hydro Power Plant in Hink River. Procedia Environmental Sciences, 20, 55-63. https://doi.org/ 10.1016/j.proenv.2014.03.009

Pieters, P. E. (1990). Geologi Lembar Ransiki, Irian Jaya. Departemen Pertambangan dan Energi, Direktorat Jenderal Geologi dan Sumberdaya Mineral, Pusat Penelitian dan Pengembangan Geologi.

Pratama, F. S. (2016). Potensi Pembangkit Listrik Tenaga Mikrohidro dan Pemanfaatannya untuk Masyarakat di Daerah Aliran Sungai Cikurai [Universitas Pendidikan Indonesia]. http:// repository.upi.edu/26681/

Pusat Data dan Teknologi Informasi ESDM. (2017). Kajian Penyediaan dan Pemanfaatan Migas, Batubara, EBT dan Listrik. Pusat Data dan Teknologi Informasi ESDM. 
Robinson, G. P. (1990). Geologi Lembar Steenkool, Irian Jaya. Pusat Penelitian dan Pengembangan Geologi.

Tobi, M. D., \& van Harling, V. N. (2017). Studi Perencanaan Pembangunan PLTMH di
Kampung Sasnek Distrik Sawiat Kabupaten Sorong Selatan Provinsi Papua Barat. Electro Luceat, 3(1), 32-43. https: / / doi.org/10.32531/jelekn.v3i1.63 